KAZIMIERZ W. KRUPA

Uniwersytet Rzeszowski

\title{
Ekonomiczne i technologiczne strefy rozwoju Chin (kwantyfikacja, stratyfikacja, metodyka)
}

\author{
OperacjonalizaCja POLITYKi OTWARCia Chin \\ NA MIĘDZYNARODOWĄ WSPÓŁPRACĘ GOSPODARCZA
}

Ekonomiczne i technologiczne strefy rozwoju (Economic and Technological Development Zones - ETDZ) Chin są rezultatem polityki otwarcia ekonomicznego czternastu miast portowych. W jej ramach w latach 1984-1988 powołano 12 stref, w obrębie których jest obecnie realizowana specjalna polityka gospodarczej integracji. Operacyjnie administracyjne komitety Economic and Technological Development Zones (wybierane głównie z lokalnych władz) nadzorują ekonomiczne i socjalne zarządzanie w strefach wspólnie z lokalną administracją. Klasycznym przykładem wyników funkcjonowania takich rozwiązań jest dystrykt $\mathrm{w}$ delcie rzeki Pearl. Obejmuje on miasta w prowincji Guangdong. Jest to jednak przypadek odmienny od Szanghajskiej Strefy Ekonomicznej, która w 1990 r. wyrosła na samodzielnego lidera ETDZ w Chinach (fot. 1).

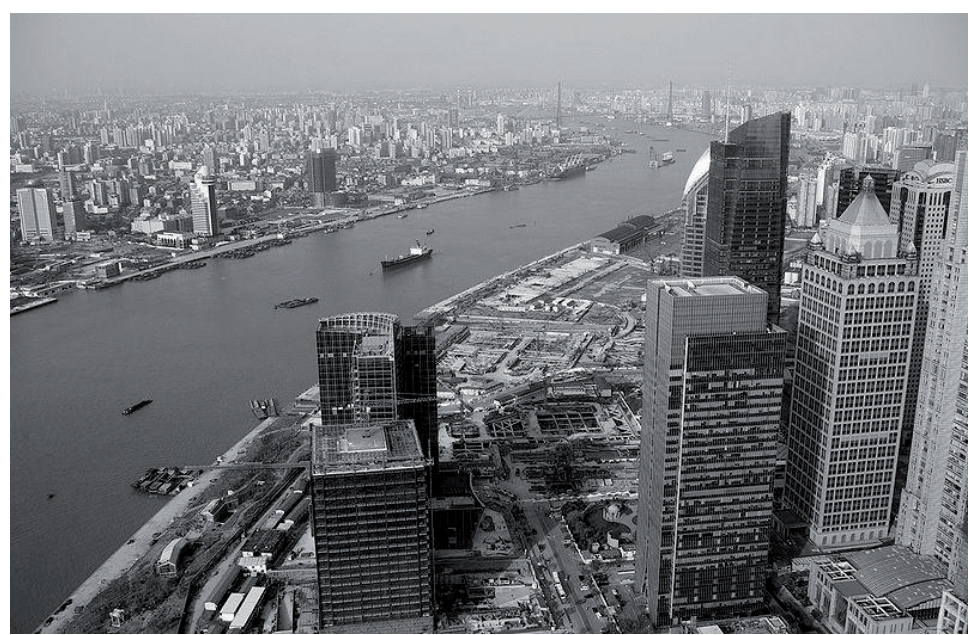

Fot. 1. Strefa biznesowa Szanghaju w delcie rzeki Jangcy

Źródło: China Knowledge 
W rezultacie pozytywnych efektów, głównie społecznych i gospodarczych, politykę wspierania otwarcia ekonomicznego w dalszym ciągu intensyfikowano i w latach 1992-1993 założono 18 kolejnych ekonomicznych stref. Są to: Yingkou, Changchun, Shenyang, Harbin, Weihai, Kunshan, Hangzhou, Xiaoshan, Wenzhou, Rongqiao, Dongshan, Guangzhou Nansha, Huizhou Daya Bay, Wuhu, Wuhan, Chongqing, Beijing oraz Urumchi. Uruchomiono również dwie nowe innowacyjne formy współpracy w ramach ogólnej polityki free zone. Są to: Ningbo Daxie Development Zone powołana w 1993 r. przez China International Trust i Investment Corporation (CITIC) oraz Suzhou Industrial Park uruchomiony w 1994 r. jako joint venture pomiędzy Chinami i Singapurem. Po 2000 r. rząd Chin w ramach kolejnego strategicznego programu znacznego przyspieszenia rozwoju centralnych i wschodnich prowincji intensywnie promuje i wspomaga powołanie kolejnych 12 stref, które są obecnie przykładem dynamicznego rozwoju Chin (fot. 2). Aktualnie funkcjonują w Chinach 54 specjalne strefy ekonomiczne, z tego $32 \mathrm{w}$ regionach nadmorskich, a 22 wewnątrz kraju (tab. 1). CKRS stratyfikuje w nich 253 CPP.

Tab. 1. Ekonomiczne i technologiczne strefy rozwoju w Chinach

\begin{tabular}{|c|c|c|c|}
\hline \multicolumn{2}{|c|}{ Przybrzeżne regiony } & \multicolumn{2}{|c|}{ Wewnętrzne regiony } \\
\hline Region & Nazwa ETDZ & Region & Nazwa ETDZ \\
\hline Beijing & Beijing & Chongqing & Chongqing \\
\hline \multirow{4}{*}{ Shanghai } & Minhang & \multirow{4}{*}{ Anhui } & Wuhu \\
\hline & Hongqiao & & Hefei \\
\hline & Caohejing & & \\
\hline & Jinqiao EPZ & & \\
\hline Tianji & Tianjin (TEDA) & Gansu & Lanzhou \\
\hline \multirow{4}{*}{ Fujian } & Fuzhou & \multirow{4}{*}{ Guangxi } & Nanning \\
\hline & Dongshan (w Xiamen) & & \\
\hline & Rongqiao (w Fuqing) & & \\
\hline & Haichang & & \\
\hline \multirow{4}{*}{ Guangdong } & Guangzhou & \multirow{4}{*}{ Guizhou } & Guiyang \\
\hline & Zhanjiang & & \\
\hline & Nansha (w Guangzhou) & & \\
\hline & Daya Bay (w Huizhou) & & \\
\hline Hainan & Yangpu & Heilongjiang & Harbin \\
\hline Hebei & Qinhuangdao & Henan & Zhengzhou \\
\hline \multirow{5}{*}{ Jiangsu } & Lianyungang & \multirow{5}{*}{ Hubei } & Wuhan \\
\hline & Nanjing & & \\
\hline & Nantong & & \\
\hline & Kunshan & & \\
\hline & Suzhou Industrial Park & & \\
\hline \multirow{3}{*}{ Liaoning } & Dalian & \multirow{3}{*}{ Hunan } & Changsha \\
\hline & Yingkou & & \\
\hline & Shenyang & & \\
\hline \multirow{3}{*}{ Shandong } & Yantai & \multirow{3}{*}{ Inner Mongolia } & Hohhot \\
\hline & Qingdao & & \\
\hline & Weihai & & \\
\hline
\end{tabular}




\begin{tabular}{|c|c|c|c|}
\hline \multirow{5}{*}{ Zhejiang } & Ningbo & \multirow{5}{*}{ Jiangxi } & Nanchang \\
\hline & Hangzhou & & \\
\hline & Xiaoshan & & \\
\hline & Wenzhou & & \\
\hline & Daxie (Ningbo city) & & \\
\hline & & Jilin & Changchun \\
\hline & & Ningxia & Yinchuan \\
\hline & & Qinghai & Xining \\
\hline & & Shaanxi & Xi'an \\
\hline & & Shanxi & Taiyuan \\
\hline & & Sichuan & Chengdu \\
\hline & & Tibet & Lhasa \\
\hline & & Xiniiang & Urumqi \\
\hline & & xinjlang & Shihezi \\
\hline & & Yunnan & Kunming \\
\hline
\end{tabular}

Źródło: China Knowledge

ETDZ Chin zachęcają do innowacyjnego inwestowania w poszczególnych miastach, obszarach oraz całych regionach, wspomagając globalną dyfuzję innowacyjnych łańcuchów podażowych. Niemal wszystkie funkcjonujące już obecnie specjalne strefy oferują szczególnie atrakcyjne wspomaganie kreatywnego przemysłu w innowacyjnych aglomeracjach, np. Pudong w Szanghaju (fot. 3-5). Oficjalna bardzo wysoka ocena roli większości z nich w zakresie promowania nowoczesnego zarządzania, inspirujących inwestycji, nowoczesnej infrastruktury i innych wyjątkowo skutecznych akceleratorów wskazuje, że polityka Chin w zakresie free zones powinna być dobrym wzorem dla innych państw w rejonie wschodniej Azji (więcej w: www.google.pl/search?hl=pl\&source=hp\&q= china $+\mathrm{CK}+\mathrm{Rati}$ ).

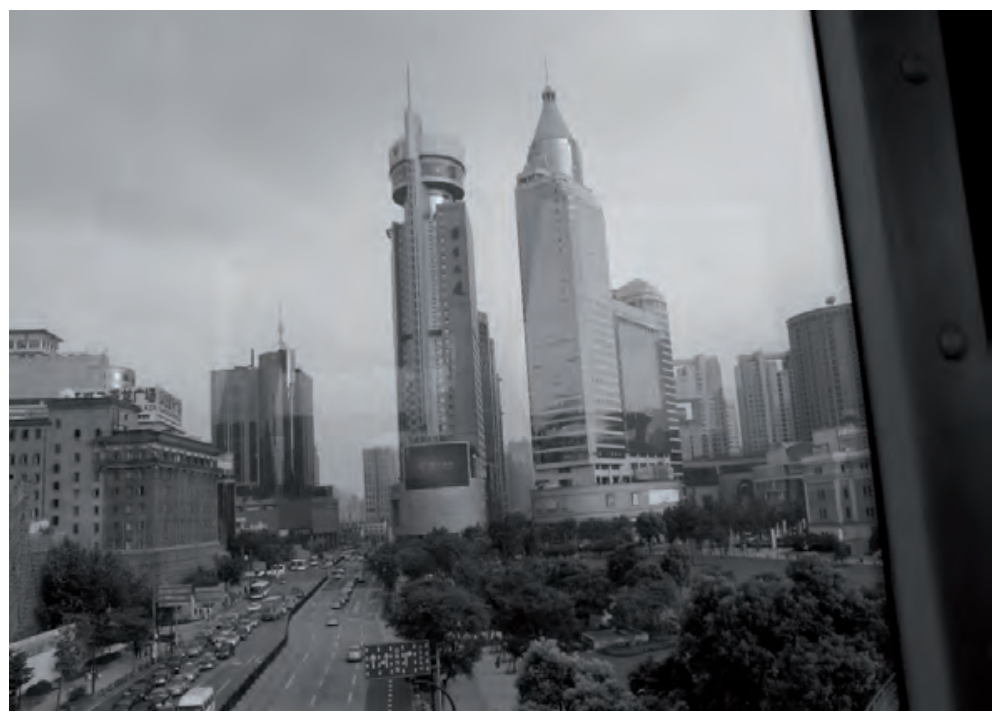

Fot. 2. Pekin - przykład dynamicznego rozwoju na skalę światową 


\section{Kwantyfikatory rankingu parków przemysłowych funkcjonujących w Chinach}

Ranking parków przemysłowych (CK - China Knowledge) funkcjonujących w Chinach dokonuje ich kwantyfikacji i stratyfikacji, analizując pięć kategorii. Są to:

1. Makroekonomiczne rezultaty w stratyfikacji lokalnej aktywności przemysłowej;

2. Wielkość bezpośrednich finansowych inwestycji i operacyjnych kosztów;

3. Poziom nowoczesności parku przemysłowego;

4. Skuteczność wykorzystywanych instrumentów Human Relation (HR);

5. Nowoczesność i jakość systemu zarządzania oraz kierowania.

Każda z tych kategorii posiada po kilka kwantyfikatorów szczegółowych oceniających:

- wpływ na miasto,

- innowacyjność parku przemysłowego,

- koszty,

- HR - politykę personalną,

- zarządzanie (tab. 2).

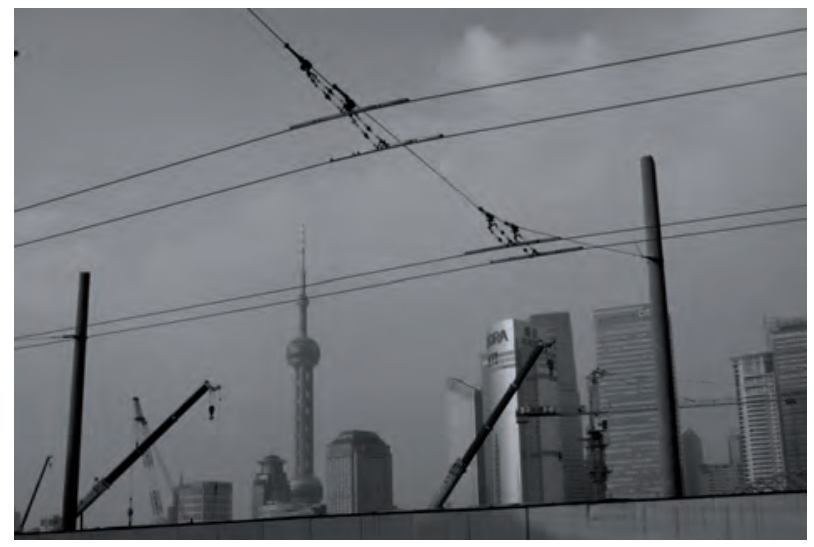

Fot. 3. Szanghaj - innowacyjna infrastruktura

fot. autor

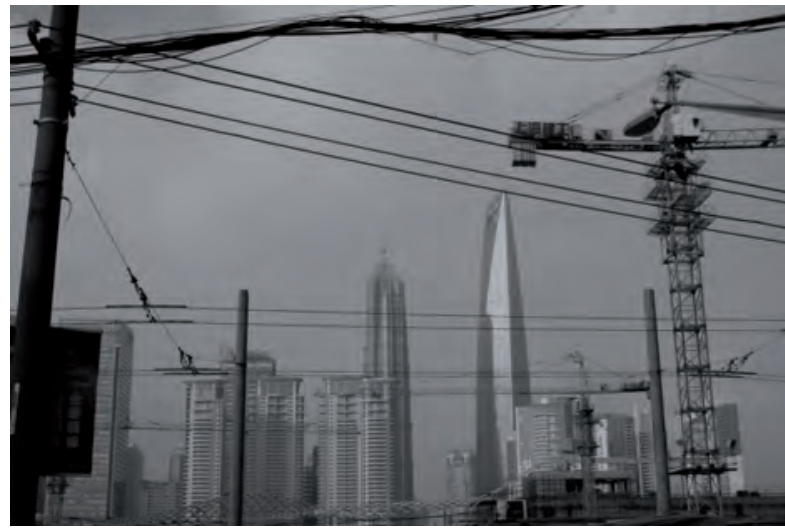

Fot. 4. Szanghaj - wielki plac budowy 


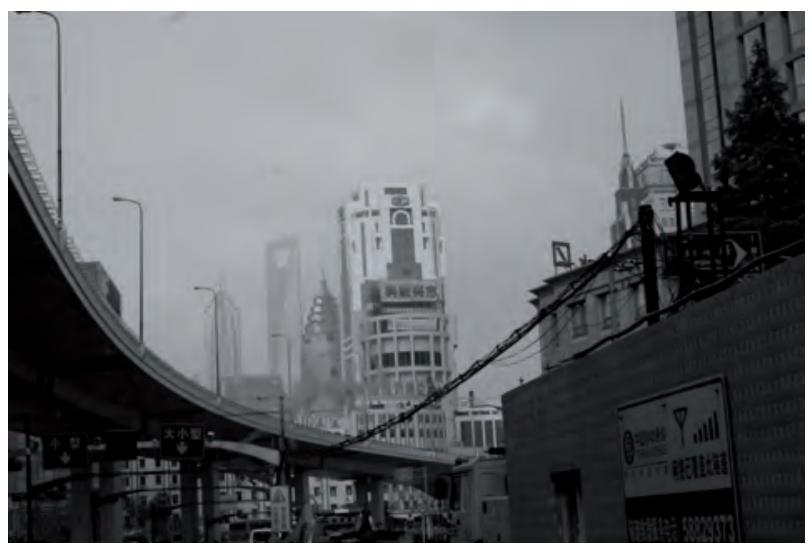

Fot. 5. Szanghaj - nowoczesne rozwiązania komunikacyjne

fot. autor

Tab. 2. Kwantyfikatory dla kategorii Makroekonomiczne rezultaty w stratyfikacji lokalnej aktywności przemystowej

\begin{tabular}{|c|c|}
\hline Zakres oddziaływania & Kwantyfikator \\
\hline \multirow{7}{*}{ Wpływ na miasto } & GDP \\
\hline & Wzrost GDP \\
\hline & Trwałe aktywa inwestycyjne \\
\hline & Komórki handlowe \\
\hline & Finansowy serwis \\
\hline & Inspiracja rozwoju lokalnego \\
\hline & Ruch uliczny \\
\hline \multirow{4}{*}{ Park przemysłowy } & Wartość dodana inwestycji \\
\hline & Infrastruktura \\
\hline & Bezpośrednie inwestycje zagraniczne \\
\hline & Eksport \\
\hline \multirow{4}{*}{ Koszty } & Podatki \\
\hline & Woda \\
\hline & Elektryczność \\
\hline & Siła robocza \\
\hline \multirow{2}{*}{ HR - polityka personalna } & Uniwersytety \\
\hline & Szkoły techniczne \\
\hline \multirow{4}{*}{ Zarządzanie } & Administracja \\
\hline & Promowanie inwestycji \\
\hline & Ochrona praw własności intelektualnej \\
\hline & Ochrona środowiska \\
\hline
\end{tabular}

Źródło: China Knowledge 
Tab. 3. System stratyfikacji dla kategorii Wielkość bezpośrednich finansowych inwestycji i operacyjne koszty

\begin{tabular}{|c|c|c|c|}
\hline Zakres oddziaływania & $\begin{array}{c}\text { Udział } \\
\text { procentowy }\end{array}$ & Kwantyfikator & $\begin{array}{c}\text { Udział } \\
\text { procentowy }\end{array}$ \\
\hline \multirow{7}{*}{ Wpływ na miasto } & \multirow{7}{*}{$30 \%$} & GDP & $20 \%$ \\
\hline & & Wzrost GDP & $5 \%$ \\
\hline & & Trwałe aktywa inwestycyjne & $10 \%$ \\
\hline & & Komórki handlowe & $15 \%$ \\
\hline & & Finansowy serwis & $10 \%$ \\
\hline & & Inspiracja rozwoju lokalnego & $10 \%$ \\
\hline & & Ruch uliczny & $30 \%$ \\
\hline \multirow{4}{*}{ Park przemysłowy } & \multirow{4}{*}{$40 \%$} & Wartość dodana inwestycji & $50 \%$ \\
\hline & & Infrastruktura & $15 \%$ \\
\hline & & Bezpośrednie inwestycje zagraniczne & $20 \%$ \\
\hline & & Eksport & $15 \%$ \\
\hline \multirow{4}{*}{ Koszty } & \multirow{4}{*}{$10 \%$} & Podatki & $30 \%$ \\
\hline & & Woda & $20 \%$ \\
\hline & & Elektryczność & $20 \%$ \\
\hline & & Siła robocza & $30 \%$ \\
\hline \multirow{2}{*}{ HR - polityka personalna } & \multirow{2}{*}{$10 \%$} & Uniwersytety & $40 \%$ \\
\hline & & Szkoły techniczne & $60 \%$ \\
\hline \multirow{4}{*}{ Zarządzanie } & \multirow{4}{*}{$10 \%$} & Administracja & $30 \%$ \\
\hline & & Promowanie inwestycji & $30 \%$ \\
\hline & & Ochrona praw własności intelektualnej & $20 \%$ \\
\hline & & Ochrona środowiska & $20 \%$ \\
\hline
\end{tabular}

Źródło: China Knowledge

Przedstawione wskaźniki atrakcyjności inwestycyjnej uwzględniają często odmienny poziom preferencji różnych grup inwestorów w wyżej wspomnianych kategoriach. Dotyczy to przykładowo wskaźników: wptyw na miasto i natężenie ruchu ulicznego. Mogą one być bardzo ważne, szczególnie dla produkcji, którą inwestor planuje uruchomić w centrum miasta. Natomiast indykatory: poziom nowoczesności produkcji i nakłady na B\&R są określane jako kluczowe dla wzrostu inwestycji w parkach przemysłowych i preferowane przez lokalną administrację Chin, bowiem szczególnie energicznie wspomagają rozwój kreatywności indywidualnej w zrównoważonym rozwoju. Dotychczasowe doświadczenia wskazują, że odpowiednia wielkość tych kwantyfikatorów może również wspomagać osiągnięcie właściwej siły absorpcyjnej ewaluowanych parków. Opracowany przez technologiczne strefy rozwoju oryginalny system oceny udziału procentowego tych kwantyfikatorów przedstawiają tabele 3 i 4. 


\section{METODOLOGIA STRATYFIKACJI PARKÓW PRZEMYSŁOWYCH}

Każdego roku parki przemysłowe Chin są ewaluowane i w rezultacie stratyfikacji prezentowane w standardowym oficjalnym rankingu. System ratingu parków przemysłowych realizowany jest przez zespół profesjonalistów CK (China Knowledge). Kwantyfikując chińskie parki przemysłowe:

- wykorzystują oni oryginalne instrumenty,

- dokonują wizyt sondażowych,

- przeprowadzają wywiady środowiskowe.

Tab. 4. System stratyfikacji dla kategorii Poziom nowoczesności rozwoju parku przemysłowego

\begin{tabular}{|c|c|c|c|}
\hline Zakres oddziaływania & $\begin{array}{c}\text { Udział } \\
\text { procentowy }\end{array}$ & Kwantyfikator & $\begin{array}{c}\text { Udział } \\
\text { procentowy }\end{array}$ \\
\hline \multirow{7}{*}{ Wpływ na miasto } & \multirow{7}{*}{$20 \%$} & GDP & $25 \%$ \\
\hline & & Wzrost GDP & $10 \%$ \\
\hline & & Trwałe aktywa inwestycyjne & $20 \%$ \\
\hline & & Komórki handlowe & $10 \%$ \\
\hline & & Finansowy serwis & $25 \%$ \\
\hline & & Inspiracja rozwoju lokalnego & $0 \%$ \\
\hline & & Ruch uliczny & $10 \%$ \\
\hline \multirow{4}{*}{ Park przemysłowy } & \multirow{4}{*}{$15 \%$} & Wartość dodana inwestycji & $20 \%$ \\
\hline & & Infrastruktura & $20 \%$ \\
\hline & & Bezpośrednie inwestycje zagraniczne & $50 \%$ \\
\hline & & Eksport & $10 \%$ \\
\hline \multirow{4}{*}{ Koszty } & \multirow{4}{*}{$20 \%$} & Podatki & $30 \%$ \\
\hline & & Woda & $15 \%$ \\
\hline & & Elektryczność & $15 \%$ \\
\hline & & Siła robocza & $40 \%$ \\
\hline \multirow{2}{*}{ HR - polityka personalna } & \multirow{2}{*}{$25 \%$} & Uniwersytety & $80 \%$ \\
\hline & & Szkoły techniczne & $20 \%$ \\
\hline \multirow{4}{*}{ Zarządzanie } & \multirow{4}{*}{$20 \%$} & Administracja & $10 \%$ \\
\hline & & Promowanie inwestycji & $20 \%$ \\
\hline & & Ochrona praw własności intelektualnej & $50 \%$ \\
\hline & & Ochrona środowiska & $20 \%$ \\
\hline
\end{tabular}

Źródło: China Knowledge

W efekcie powstają analityczne dokumenty przekazywane do centrów strategicznych rządu oraz stanowiące materiały źródłowe dla działań reklamowych i promocyjnych regionów i całych prowincji. W 2009 r. Centralna Instytucja Ratingowa Chin (China Knowledge Rating System - CKRS), dokonująca oceny siły parków przemysłowych, zaproponowała nową metodologię online procesu doskonalenia narzędzi stratyfikacji. Objęto nią 253 funk- 
cjonujące Chińskie Parki Przemysłowe $(\mathrm{CPP})^{1}$. W tych rozwiązaniach pozycjonowanie CPP na mapie przemysłowej Chin w zamiarze pomysłodawców i ekspertów CK ma pomagać potencjalnym inwestorom $\mathrm{w}$ dokonywaniu trafnych alokacji finansowych, adekwatnych do realnych ich oczekiwań i determinowanych coraz częściej możliwościami globalnych wyborów. Dotyczy to głównie strategicznych kierunków lokowania środków finansowych w przedsięwzięcia, np. green friendly czy nano scale, zgodnie z preferencjami akcjonariuszy oraz indywidualnymi biznesowymi oczekiwaniami CEO w zakresie:

- technologicznego poziomu strefy,

- jej ekonomicznego potencjału,

- high-tech parku,

- zakresu i siły narzędzi wolnej strefy,

- finansowego wsparcia eksportowego.

Zgodnie z obecnie obowiązującymi normatywami system rankingu dzieli Chińskie Parki Przemysłowe na siedem grup oznaczonych od AAA do C.

\section{Grupa AAA}

Jest oceną najwyższą. Parki przemysłowe tej grupy posiadają bardzo wysoki poziom rozwoju technologicznego, ich inwestycje są bardzo duże i przyczyniają się do wzrostu nowoczesności. Parki z grupy AAA są zaliczane do obszarów kreatywnych, a przez centra decyzyjne Chin silnie rekomendowane jako wyjątkowo interesujące miejsca lokowania innowacyjnych inwestycji.

\section{Grupa AA}

Parki przemysłowe zakwalifikowane do tej grupy są również atrakcyjne do inwestycji oraz w wysokim stopniu rekomendowane. Jednak w porównaniu z grupą AAA pozostają w tyle w możliwościach wykorzystania innowacyjności generowanej przez globalną gospodarkę. Zdaniem centrum strategicznego zarządzania Chin najwięcej kreatywnej aktywności jest generowane w small biznesie (z punktu widzenia GDB oraz FDI), a duży koszt innowacyjnych inwestycji jest determinantem rozwoju obszarów, w którym strefa i podmioty tej klasy są zlokalizowane. Aktualna polityka ekonomiczna Chin zakłada, że rozwój parków w grupie AA wymaga bardzo istotnego wsparcia systemowego przez lokalnych decydentów zarządzających w regionach.

\section{Grupa A}

Parki przemysłowe należące do tej grupy posiadają przeciętne potrzeby inwestycyjne. Ich bazowa kondycja jest zazwyczaj adekwatna do konieczności unowocześniania biznesu. Dotychczasowa praktyka gospodarcza wskazuje jednoznacznie, iż cała grupa parków przemysłowych oznaczonych jako A należy do najwcześniej powołanych.

\section{Grupa BBB}

Skupia parki, które pod względem atrakcyjności inwestowania zaliczane są do przeciętnych. Posiadają adekwatny poziom inwestycji, które wspomagają główne potrzeby modernizacyjne tam funkcjonujących podmiotów gospodarczych. Należy je w zasadzie traktować jako „niezdecydowane” pod względem przyszłościowego rozwoju.

\section{Grupa BB}

Parki przemysłowe zaliczone do grupy BB są atrakcyjne w mniejszym zakresie. Są one typowe dla ekstensywnych rodzajów rozwoju inwestycji lub są zarezerwowane dla pewnych ściśle zdeterminowanych, lecz ważnych dziedzin aktywności ekonomicznej.

\footnotetext{
${ }^{1}$ Więcej w: Updated ratings for Chinese industrial parks 2009. www.chinaknowledge.com
} 


\section{Grupa B}

Parki przemysłowe zaliczone do grupy B są obszarem, który cieszy się małym zainteresowaniem nowoczesnego establishmentu. Konieczny jest duży wysiłek organizacyjny i inwestycyjny centrów decyzyjnych dla polepszenia ich kreatywności.

\section{Grupa C}

Parki przemysłowe zaliczone do grupy $\mathrm{C}$ nie są atrakcyjne. Inwestowanie w tego rodzaju parkach nie jest rekomendowane.

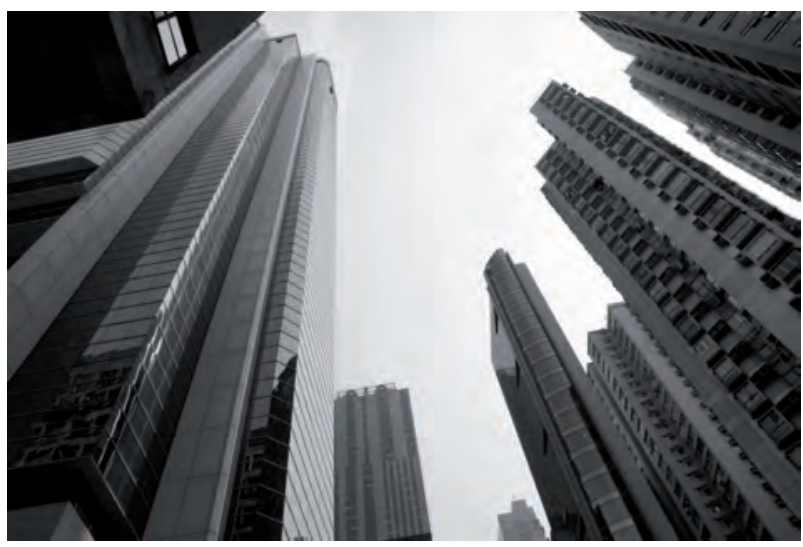

Fot. 6. Hongkong - centrum biznesowe Azji

fot. autor

Każdy z inwestorów zainteresowanych uruchomieniem działalności biznesowej w regionach, w których funkcjonują parki przemysłowe, może sprawdzić ich atrakcyjność mierzoną przez CKRS w trybie online na stronie http://www.chinaknowledge.com/ Manufacturing/ Introduction. aspx? subchap $=4 \&$ content $=21$. Źródłowe dane $\mathrm{z}$ raportów są całościowe, właściwie pozycjonowane dla poszczególnych geograficznych regionów oraz przemysłów. Dają one również wiedzę o aktualnym stanie zmian doskonalących ich infrastrukturę. Miejsce w tym rankingu pokazuje także realnie zakres osiagnnięć powstałych w wyniku różnych badawczych inicjatyw i przedsiębiorczości kapitału intelektualnego. Na liście dziesięciu najwyżej ocenionych w 2009 r. są parki oraz strefy wolnocłowe z funkcjonującymi tam ekonomiczno-technologicznymi obszarami, głównie z rejonów nadmorskich, w tym po dwa z Szanghaju i Suzho (tab. 4).

Tab. 4. Lista najwyżej ocenionych w 2009 roku parków oraz stref wolnocłowych w Chinach

\begin{tabular}{|l|l|}
\hline Lp. & Nazwa parku przemysłowego lub strefy wolnocłowej \\
\hline 1. & $\begin{array}{l}\text { Tianjin Economic-Technological Development Area (TEDA) wraz z Tianjin Port Export } \\
\text { Processing Zone }\end{array}$ \\
\hline 2. & Qingdao Economic i Technological Development Zone \\
\hline 3. & $\begin{array}{l}\text { Guangzhou Development District wraz z: } \\
\text { a) Guangzhou Economic i Technological Development Zone } \\
\text { b) Guangzhou High-tech Indsutrial Development Zone } \\
\text { c) Guangzhou Free Trade Zone, Guangzhou Export }\end{array}$ \\
\hline
\end{tabular}




\begin{tabular}{|l|l|}
\hline 4. & Processing Zone \\
\hline 5. & $\begin{array}{l}\text { Shanghai Zhangjiang High-tech Park } \\
\text { China-Singapore Suzhou Industrial Park wraz z Suzhou Industrial Park Export }\end{array}$ \\
\hline 6. & Processing Zone \\
\hline 7. & Suzhou New District wraz z Suzhou New District Export Processing Zone \\
\hline 8. & Shanghai Jinqiao Export Processing Zone \\
\hline 9. & Kunshan Economical and Technological Development Zone \\
\hline 10. & $\begin{array}{l}\text { Dalian Economic and Technological Development Zone } \\
\text { Zhongguancun Science Park }\end{array}$ \\
\hline
\end{tabular}

Źródło: China Knowledge

Oddzielną i specyficzną pozycję w rankingu aktywności biznesowej współczesnych Chin odgrywa Hongkong. Jego siła ekonomiczno-gospodarcza została zbudowana na wieloletniej wymianie towarowej ChRL ze światem. Obecnie pełni on głównie rolę jednego ze światowych centrów handlowo-finansowych (fot. 6-7).

Charles Chaw, dyrektor zarządzający China Knowledge, twierdzi, że wyniki badania poziomu parków przemysłowych spotykają się z dużym zainteresowaniem potencjalnych inwestorów. Deklaruje on jednocześnie, iż w dalszym ciągu będzie prowadzone i prezentowane pozycjonowanie standingu parków na podstawie kwantyfikatorów. CK w kolejnych strategicznych założeniach przewiduje aktywny udział w kreowaniu nowych inicjatyw i ma nadzieję, że zostaną one dobrze przyjęte przez zainteresowane strony, tj. międzynarodowy biznes, przedstawicieli kierownictwa parków przemysłowych, lokalnych inwestorów oraz regionów, w których się rozwijają. Szczególnie w dobie doskonalenia wzorców projektowych globalnego biznesu, np. Session Facade (SF). Umożliwiają one bowiem skuteczne rozwiązywanie współczesnych problemów udostępniania komponentów i usług biznesowych klientom, szczególnie gdy występuje:

- brak zależności między klientem i warstwą biznesową;

- centralizacja logiki biznesowej;

- ukrycie zależności w warstwie realizacyjnej;

- sesyjność komponentów EJB (Enterprise JavaBeans);

- potrzeba poprawy aplikacyjności i skuteczności rozwiązań oraz wykorzystywanych instrumentów.

Jednak bezpośrednie udostępnienie usług warstwy biznesowej klientom może mieć niekorzystny wpływ, szczególnie na strukturę rozwiązań aplikacyjnych. W takim przypadku klienci stają się mocno związani z interfejsem warstwy biznesowej, co zmniejsza elastyczność i znacznie podnosi koszt wprowadzania ewentualnych zmian w dziedzinie rozwiązań praktycznych. Jednoznacznie bezpośrednie operowanie na komponentach biznesowych wymaga od klientów implementacji złożonej logiki funkcjonowania biznesu i oprogramowania, w realiach wyrafinowanych interakcji pomiędzy komponentami wykonawczymi, realizowanymi obecnie już głównie w trybie online. Nowocześni i kreatywni klienci muszą być więc świadomi szczegółów przetwarzania transakcyjnego, zarządzania bezpieczeństwem oraz procedur kontroli dostępu. Oferowane jednak obecnie rozwiązanie Session Facade (SF) umożliwia skuteczne „ukrycie” złożonych zależności i związków między komponentami biznesowymi za tzw. fasadą procedur sesyjnych. Udostępnienia on również klientom interfejsu warstwę biznesową w spójny i stosunkowo prosty sposób. 
Gestorzy rynku gospodarczego uzyskują dzięki temu wzorcowi niezależność między warstwą klienta i warstwą biznesową. Natomiast kompletna logika aplikacyjna zostaje scentralizowana w warstwie prezentacji, zwiększa się więc tak oczekiwana obecnie w realiach globalizacji gospodarki modułowość i elastyczność aplikacji. Dodatkowo zestaw komponentów tworzących jądro wzorca Session Facade może publikować interfejs warstwy realizacyjnej zgodny z logiką wymagań biznesowych, a nie bazą komponentów aplikacyjnych reprezentowanych poprzez poszczególne encje. Wzorzec Session Facade jest implementowany najczęściej za pomocą stanowych komponentów sesyjnych EJB, choć zdarzają się implementacje wykorzystujące bezstanowe elementy sesyjne Enterprise JavaBeans. Wzorzec Session Facade jest zalecany w każdej dużej, szczególnie biznesowej aplikacji webowej, a jego zastosowanie ma pozytywny wpływ na praktycznie każdy aspekt aplikacji, w tym szczególnie ujednolicenie interfejsu, zmniejszenie zależności między warstwami, zwiększenie elastyczności, zmniejszenie złożoności, centralizację zarządzania transakcjami i bezpieczeństwo rozwiązań finałowych.

\section{Literatura}

Hučka M., Mikolas Z., Ludvík L., 2009, Vliv Investic A Transformace Regionu Nauniverzity, [w:] Podnikanie a konkurencieschopnost' firiem, Bratislava.

Kislingerová E., 2009, Aktuálni situace v podnikové sféré, [w:] Podnikanie a konkurencieschopnost' firiem, Bratislava.

Krupa K.W., 2009, Ekonomiczne narzędzia gospodarki opartej na technologii cyfrowej, t. 1-2, UR, Rzeszów.

Krupa W.K., 2009, TBE ${ }^{S M}$ nowej ekonomii, BUI „Mikro-Serve”, Warszawa.

Krupa W.K., 2007, Dilemmas New Economy. Methodology, methods, tools, case, TIB, Ekonómicka Fakulta, Koŝice.

Kuusela M., 2008, Islamin opettaja, Aamulehti, Viikko 5, no 33, B19.

Mankani D., 2007, Technopreneurship: The Successful Entrepreneur in the New Economy, Pearson Education Asia.

Soni V., 2008, An ode to Energy and Youth, „Hindustan Times”, New Delhi, february 4.

Štverková, H. 2004, Analýza současného stavu a návrh rozvoje společnosti, Diplomová práce, Ostrava: Ekonomická fakulta, Vysoká škola báňská - Technická univerzita Ostrava.

Štverková, H. 2008, Zákon o registračnich pokladnách, [w:] Sborník přispěvků ze VIII. ročníku mezinárodni konference „Mekon 2006“, Ostrava: Ekonomická fakulta, Vysoká škola báňská Technická universita Ostrava.

Updated ratings for Chinese industrial parks 2009 May. 26, 2009 (Singapore).

Zmeskal Z., 2008, The application of the American real flexible switch options methodology a generalised approach, Finance a úvr, „Czech Journal of Economics and Finance”, Vol. 58, Issue: 5-6, pp. 261-275.

\section{Economic and Technological Development Zones in China (quantification, stratification, methodology)}

As a result of the new economic policy, fourteen Economic and Technological Development Zones (ETDZs) were established in twelve coastal cities between 1984 and 1988. The first ETDZs were Dalian, Yantai, Qingdao, Lianyungang, Nantong, Minhang (Shanghai), Hongqiao (Shanghai), 
Caohejing (Shanghai), Ningbo, Fuzhou, Guangzhou and Zhanjiang. Unlike Special Economic Zone (SEZ), an ETDZ is located in the suburban area of a major city. Special policies are adopted within the ETDZ. An administrative committee, normally selected by the local government, oversees economic and social management in the zones on behalf of the local government. The category 'SEZ' covers a broad range of more specific zone types, including Free Trade Zones (FTZ), Export Processing Zones (EPZ), Free Zones (FZ), Industrial Estates (IE), Free Ports, Urban Enterprise Zones and others. The second wave of expansion of ETDZs was led by the establishment of Pudong New District in Shanghai in 1990. This decision was aimed at elevating the status of Shanghai, making it the "Dragon Head" of the Yangtze River Delta Region, which comprises of Shanghai and parts of Jiangsu and Zhejiang. Prior to the establishment of this new district, the Pearl River Delta Region - comprising nine cities in Guangdong - was the forerunner of China's open door policy. However, unlike Guangdong, which lies at the south-eastern coast of China, Shanghai's economic development will have more impact on China's vast hinterland. Between 1992 and 1993, a total of eighteen state-level ETDZs were established - Yingkou, Changchun, Shenyang, Harbin, Weihai, Kunshan, Hangzhou, Xiaoshan, Wenzhou, Rongqiao, Dongshan, Guangzhou Nansha, Huizhou Daya Bay, Wuhu, Wuhan, Chongqing, Beijing and Urumchi. Two special projects were added later. Founded in 1993, the Ningbo Daxie Development Zone is an investment by China International Trust and Investment Corporation (CITIC), and comes under its management. The other special project is the Suzhou Industrial Park, which was founded in 1994, and is a joint cooperation between the governments of China and Singapore. After 2000, in an effort to fuel the development of the Central and Western regions, the central government also endorsed the establishment of a further eleven national ETDZs in inland regions. Up till now, China has a total of fifty-four state-level ETDZs - thirty-two in coastal regions, and twenty-two in the hinterland. The region of Hong Kong has a role and status of innovation. The planners in this unique part of East Asia expect that some new concepts can help the former British colony to embrace a new economic model: a model in which design, marketing and branding play the crucial role in economy.

Prof. UR dr hab. inż. Kazimierz W. Krupa

Uniwersytet Rzeszowski

Wydział Ekonomii

e-mail: kkrupa@epf.pl

www.kkrupa.pl 